\title{
New records of Pennatulacea (Anthozoa: Octocorallia) from the African Atlantic coast, with description of a new species and a zoogeographic analysis*
}

\author{
PABLO J. LÓPEZ-GONZÁLEZ1 ${ }^{1}$ JOSEP-MARIA GILI² and GARY C. WILLIAMS ${ }^{3}$ \\ ${ }^{1}$ Laboratorio de Biología Marina, Facultad de Biología, Universidad de Sevilla, Reina Mercedes 6, 41012-Sevilla, Spain. \\ ${ }^{2}$ Instituto de Ciencias del Mar, Plaça del Mar s/n, 08039 Barcelona, Spain. \\ ${ }^{3}$ California Academy of Sciences, Department of Invertebrate Zoology, Golden Gate Park, San Francisco, \\ California. 94118 U.S.A.
}

\begin{abstract}
SUMMARY: A collection of pennatulaceans from ten cruises, acquired between 1982 and 1989 from off the western African coast comprises ca. 350 specimens of 13 species. One of the cruise is from the Gulf of Guinea and eight from the Southeast Atlantic. Fifty-four stations were sampled from depths of 91-1112 m. One previously undescribed species in the genus Stylatula is reported and described as new from samples collected from the Namibian continental shelf. Considering these collections, and previous records, the pennatulaceans in the western African region show biogeographic affinities with three geographic areas: West Africa (55.5\% of the species), which comprises the Canary, Gulf of Guinea, and Benguela regions; the North Atlantic (3.7\% of the species), which represents the more widespread Atlantic taxa; and Cape Endemic (7.4\% of the species), which comprises the southern African region.
\end{abstract}

Key words: Pennatulacea, South African fauna, zoogeography, Stylatula macphersoni.

\section{INTRODUCTION}

Marine benthic fauna from the area between 20 and $30^{\circ} \mathrm{S}$ off Namibia is one of the poorly studied in the world oceans. Unlike many other regions, it was not visited by the early oceanographic expeditions, except for a few samples collected offshore by the Deutsche Tiefsee Expedition (Zibrowius and Gili, 1990). the study of the area underwent considerable expansion in the 1970s and 1980s, when the area was one of the world's most important fisheries regions (Shannon, 1985).

Studies that monitored the fisheries in the region commenced in 1979, under the project entitled

\footnotetext{
*Received July 14, 1999. Accepted October 15, 2000.
}

"Estudio de las Pesquerías del África Austral (EPAU)" [Southern African Fisheries Studies] funded by the Spanish Fisheries Administration. For over 10 years fisheries surveys were carried out using midwater trawls, purse seines, and other pelagic sampling gear. However, given the interest in the area and the dearth of information on biodiversity in the area, the Programme Director, Dr. E. Macpherson [Instituto de Ciencias del Mar (ICM), Barcelona] arranged for a series of bottom trawls to be carried out on each survey. These trawls yielded one of the best biological collections in existence for the Namibian region. Following the termination of this programme, the fisheries studies were continued, but other biological studies almost ceased. Therefore, the ICM's biological collections from the 
TABLE 1. - The station code, date, coordinates, depth, geographical area, and the species collected for each cruise.

\begin{tabular}{|c|c|c|c|c|c|}
\hline Station/Cruise & Date & Coordinates & Depth & Geographical area & Species collected \\
\hline$\overline{\text { GUINEA-BISSAU }}$ & $1984 / 85$ & & & & \\
\hline $\mathrm{P}-1$ & 29.12 .84 & $11^{\circ} \mathrm{N}-16^{\circ} 53^{\prime} \mathrm{W}$ & 27 & Guinea Bissau & \multirow{14}{*}{$\begin{array}{l}\text { Veretillum cynomorium } \\
\text { Veretillum cynomorium, } \\
\text { Cavernularia kuekenthali } \\
\text { Veretillum cynomorium } \\
\text { Veretillum cynomorium, } \\
\text { Cavernularia kuekenthali } \\
\text { Cavernularia kuekenthali } \\
\text { Pteroeides sp. } \\
\text { Veretillum cynomorium } \\
\text { Pennatula rubra } \\
\text { Veretillum cynomorium } \\
\text { Pennatula rubra } \\
\text { Veretillum cynomorium } \\
\text { Virgularia mirabilis } \\
\text { Veretillum cynomorium } \\
\text { Pteroeides sp. }\end{array}$} \\
\hline $\mathrm{P}-2$ & 29.12 .84 & $10^{\circ} 55^{\prime} \mathrm{N}-16^{\circ} 40^{\prime} \mathrm{W}$ & 25 & Guinea Bissau & \\
\hline P-4 & 29.12 .84 & $10^{\circ} 57^{\prime} \mathrm{N}-16^{\circ} 43^{\prime} \mathrm{W}$ & 32 & Guinea Bissau & \\
\hline $\mathrm{P}-21$ & 1.1 .85 & $10^{\circ} 59^{\prime} \mathrm{N}-16^{\circ} 59^{\prime} \mathrm{W}$ & 27 & Guinea Bissau & \\
\hline P-23 & 1.1 .85 & $10^{\circ} 57^{\prime} \mathrm{N}-16^{\circ} 43^{\prime} \mathrm{W}$ & 32 & Guinea Bissau & \\
\hline P-96 & 17.1 .85 & $11^{\circ} 57^{\prime} \mathrm{N}-17^{\circ} 20^{\prime} \mathrm{W}$ & $153-179$ & Guinea Bissau & \\
\hline P-106 & 19.1.85 & $11^{\circ} 50^{\prime} \mathrm{N}-17^{\circ} 21^{\prime} \mathrm{W}$ & $179-188$ & Guinea Bissau & \\
\hline P-110 & 20.1 .85 & $11^{\circ} 30^{\prime} \mathrm{N}-17^{\circ} 20^{\prime} \mathrm{W}$ & 208 & Guinea Bissau & \\
\hline P-114 & 20.1 .85 & $11^{\circ} 28^{\prime} \mathrm{N}-17^{\circ} 11^{\prime} \mathrm{W}$ & $41-44$ & Guinea Bissau & \\
\hline P-117 & 21.1 .85 & $11^{\circ} 30^{\prime} \mathrm{N}-17^{\circ} 20^{\prime} \mathrm{W}$ & 204-208 & Guinea Bissau & \\
\hline P-138 & 25.1 .85 & $11^{\circ} 42^{\prime} \mathrm{N}-17^{\circ} 19^{\prime} \mathrm{W}$ & 80 & Guinea Bissau & \\
\hline P-149 & 28.1 .85 & $11^{\circ} 23^{\prime} \mathrm{N}-17^{\circ} 22^{\prime} \mathrm{W}$ & $236-256$ & Guinea Bissau & \\
\hline P-180 & 4.2 .85 & $11^{\circ} 39^{\prime} \mathrm{N}-17^{\circ} 11^{\prime} \mathrm{W}$ & $41-44$ & Guinea Bissau & \\
\hline P-207 & 8.2 .85 & $11^{\circ} 38^{\prime} \mathrm{N}-17^{\circ} 15^{\prime} \mathrm{W}$ & $60-62$ & Guinea Bissau & \\
\hline BENGUELA V & 1983 & & & & \\
\hline P-19 & 16.7 .83 & $24^{\circ} 52.0^{\prime} \mathrm{S}-13^{\circ} 36.0^{\prime} \mathrm{E}$ & 487 & Namibia & \multirow{5}{*}{$\begin{array}{l}\text { Anthoptilum grandiflorum } \\
\text { Kophobelemnon stelliferum } \\
\text { Anthoptilum grandiflorum, } \\
\text { Kophobelemnon stelliferum } \\
\text { Kophobelemnon stelliferum } \\
\text { Amphibelemnon namibiensis }\end{array}$} \\
\hline P-16 & 16.7 .83 & $24^{\circ} 43.1^{\prime} \mathrm{S}-13^{\circ} 51.0^{\prime} \mathrm{E}$ & 267 & Namibia & \\
\hline $\mathrm{P}-21$ & 17.7 .83 & $25^{\circ} 7.0^{\prime} \mathrm{S}-13^{\circ} 43.5^{\prime} \mathrm{E}$ & 311 & Namibia & \\
\hline P-26 & 18.7 .83 & $25^{\circ} 58.4^{\prime} \mathrm{S}-13^{\circ} 54.0^{\prime} \mathrm{E}$ & 355 & Namibia & \\
\hline P-32 & 20.7 .83 & $26^{\circ} 7.5^{\prime} \mathrm{S}-14^{\circ} 5.4^{\prime} \mathrm{E}$ & 304 & Namibia & \\
\hline BENGUELA VI & 1984 & & & & \\
\hline P-3 & 12.1 .84 & $23^{\circ} 12^{\prime} \mathrm{S}-13^{\circ} 30.6^{\prime} \mathrm{E}$ & 227 & Namibia & \multirow{11}{*}{$\begin{array}{l}\text { Amphibelemnon namibiensis } \\
\text { Distichoptilum gracile } \\
\text { Halipteris africana } \\
\text { Pennatula inflata } \\
\text { Amphibelemnon namibiensis } \\
\text { Pennatula inflata } \\
\text { Halipteris africana, } \\
\text { Pennatula inflata } \\
\text { Halipteris africana } \\
\text { Pennatula inflata } \\
\text { Halipteris africana } \\
\text { Pennatula inflata }\end{array}$} \\
\hline BB-3 & 26.1 .84 & $29^{\circ} 22^{\prime} \mathrm{S}-14^{\circ} 12^{\prime} \mathrm{E}$ & 1098 & South Africa & \\
\hline BB-11 & 2.2 .84 & $25^{\circ} 53^{\prime} \mathrm{S}-5^{\circ} 44^{\prime} \mathrm{E}$ & 1112 & Walvis Ridge & \\
\hline P-12 & 14.1 .84 & $23^{\circ} 8^{\prime} \mathrm{S}-13^{\circ} 5.6^{\prime} \mathrm{E}$ & 483 & Namibia & \\
\hline P-21 & 15.1 .84 & $24^{\circ} 10.5 \mathrm{~S}-14^{\circ} 1.6^{\prime} \mathrm{E}$ & 190 & Namibia & \\
\hline P-41 & 19.1.84 & $27^{\circ} 12^{\prime} \mathrm{S}-14^{\circ} 42.7^{\prime} \mathrm{E}$ & 281 & Namibia & \\
\hline P-54 & 22.1 .84 & $29^{\circ} 3.7^{\prime} \mathrm{S}-14^{\circ} 28^{\prime} \mathrm{E}$ & 395 & South Africa & \\
\hline P-55 & 22.1 .84 & $29^{\circ} 6.5^{\prime} \mathrm{S}-14^{\circ} 36.5^{\prime} \mathrm{E}$ & 295 & South Africa & \\
\hline P-59 & 23.1 .84 & $29^{\circ} 31.6^{\prime} \mathrm{S}-14^{\circ} 33.1^{\prime} \mathrm{E}$ & 476 & South Africa & \\
\hline P-73 & 27.1 .84 & $28^{\circ} 47.6^{\prime} \mathrm{S}-14^{\circ} 22.9^{\prime} \mathrm{E}$ & 470 & South Africa & \\
\hline P-76 & 28.1 .84 & $27^{\circ} 18.2^{\prime} \mathrm{S}-14^{\circ} 9^{\prime} \mathrm{E}$ & 476 & Namibia & \\
\hline BENGUELA VII & 1984 & & & & \\
\hline P-36 & 29.7 .84 & $28^{\circ} 7.5^{\prime} \mathrm{S}-14^{\circ} 29.5^{\prime} \mathrm{E}$ & 439 & South Africa & \multirow{5}{*}{$\begin{array}{l}\text { Halipteris africana, } \\
\text { Pennatula inflata } \\
\text { Stylatula macphersoni sp. nov. } \\
\text { Amphibelemnon namibiensis } \\
\text { Amphibelemnon namibiensis } \\
\text { Anthoptilum grandiflorum, } \\
\text { Halipteris africana, } \\
\text { Pennatula inflata }\end{array}$} \\
\hline DP-56 & 3.8 .84 & $26^{\circ} 45.0^{\prime} \mathrm{S}-13^{\circ} 53.9^{\prime} \mathrm{E}$ & 425 & Namibia & \\
\hline DP-61 & 4.8 .84 & $25^{\circ} 22.7^{\prime} \mathrm{S}-13^{\circ} 47.6^{\prime} \mathrm{E}$ & 245 & Namibia & \\
\hline DP-71 & 6.8 .84 & $23^{\circ} 57.8^{\prime} \mathrm{S}-13^{\circ} 47.1^{\prime} \mathrm{E}$ & 238 & Namibia & \\
\hline P-130 & 9.8 .85 & $23^{\circ} 11.8^{\prime} \mathrm{S}-12^{\circ} 51.6^{\prime} \mathrm{E}$ & 849 & Namibia & \\
\hline BENGUELA VIII & 1985 & & & & \\
\hline P-2 & 6.7 .85 & $23^{\circ} 3.8^{\prime} \mathrm{S}-13^{\circ} 38.5^{\prime} \mathrm{E}$ & 145 & Namibia & \multirow{8}{*}{$\begin{array}{l}\text { Amphibelemnon namibiensis } \\
\text { Amphibelemnon namibiensis } \\
\text { Amphibelemnon namibiensis } \\
\text { Amphibelemnon namibiensis } \\
\text { Halipteris africana, } \\
\text { Pennatula inflata } \\
\text { Amphibelemnon namibiensis } \\
\text { Virgularia tuberculata } \\
\text { Pennatula inflata }\end{array}$} \\
\hline P-6, D-12 & 7.7 .85 & $23^{\circ} 41.3^{\prime} \mathrm{S}-13^{\circ} 58.3^{\prime} \mathrm{E}$ & 167 & Namibia & \\
\hline P-13 & 8.7 .85 & $24^{\circ} 42.0^{\prime} \mathrm{S}-14^{\circ} 33.4^{\prime} \mathrm{E}$ & 153 & Namibia & \\
\hline P-16, D-31 & 9.7 .85 & $26^{\circ} 2.2^{\prime} \mathrm{S}-14^{\circ} 31.3^{\prime} \mathrm{E}$ & 182 & Namibia & \\
\hline P-29 & 13.7 .85 & $28^{\circ} 10^{\prime} \mathrm{S}-14^{\circ} 31^{\prime} \mathrm{E}$ & 437 & South Africa & \\
\hline P-43 & 17.7 .85 & $28^{\circ} 44.0^{\prime} \mathrm{S}-16^{\circ} 16.5^{\prime} \mathrm{E}$ & 91 & South Africa & \\
\hline P-52, D-103 & 19.7 .85 & $25^{\circ} 56.3^{\prime} \mathrm{S}-13^{\circ} 58.3^{\prime} \mathrm{E}$ & 324 & Namibia & \\
\hline P-67 & 23.7 .85 & $23^{\circ} 28.2^{\prime} \mathrm{S}-13^{\circ} 5.5^{\prime} \mathrm{E}$ & 418 & Namibia & \\
\hline BENGUELA IX & 1986 & & & & \\
\hline P-29 & 3.2 .86 & $28^{\circ} 20.5^{\prime} \mathrm{S}-14^{\circ} 26.0^{\prime} \mathrm{E}$ & 439 & South Africa & Virgularia tuberculata \\
\hline BENGUELA XI & 1987 & & & & \\
\hline P-37 & 23.9.87 & $28^{\circ} 37.0^{\prime} \mathrm{S}-14^{\circ} 25.0^{\prime} \mathrm{E}$ & 220 & South Africa & Pennatula inflata \\
\hline
\end{tabular}


TABLE 1. (Cont.) - The station code, date, coordinates, depth, geographical area, and the species collected for each cruise.

\begin{tabular}{|c|c|c|c|c|c|}
\hline Station/Cruise & Date & Coordinates & Depth & Geographical area & Species collected \\
\hline $\begin{array}{l}\text { BENGUELA XIII } \\
\text { P-9 }\end{array}$ & 1988 & & & & \multirow{4}{*}{$\begin{array}{l}\text { Amphibelemnon namibiensis } \\
\text { Halipteris africana } \\
\text { Pennatula inflata } \\
\text { Stylatula macphersoni sp. nov. }\end{array}$} \\
\hline $1-9$ & $\begin{array}{l}10.7 .88 \\
17.7 .88\end{array}$ & $\begin{array}{r}24^{\circ} 10.0^{\prime} \mathrm{S}-13^{\circ} 52.0^{\prime} \mathrm{E} \\
27^{\circ} 0.0^{\prime} \mathrm{S}-14^{\circ} 25.0^{\prime} \mathrm{E}\end{array}$ & $\begin{array}{l}258 \\
414\end{array}$ & $\begin{array}{l}\text { Namibia } \\
\text { Namibia }\end{array}$ & \\
\hline P-54 & 20.7 .88 & $26^{\circ} 53.0^{\prime} \mathrm{S}-14^{\circ} 18.0^{\prime}$ & 362 & Namibia & \\
\hline BENGUELA XV & 1989 & & & & \\
\hline $\begin{array}{l}\text { PP-4 } \\
\text { PP-5 } \\
\text { PP-6 }\end{array}$ & $\begin{array}{l}5.7 .89 \\
6.7 .89 \\
6.7 .89\end{array}$ & $\begin{array}{l}23^{\circ} 36.0^{\prime} \mathrm{S}-13^{\circ} 51.0^{\prime} \mathrm{E} \\
23^{\circ} 48.0^{\prime} \mathrm{S}-14^{\circ} 6.0^{\prime} \mathrm{E} \\
24^{\circ} 2.0^{\prime} \mathrm{S}-14^{\circ} 4.0^{\prime} \mathrm{E}\end{array}$ & $\begin{array}{l}174 \\
168 \\
167\end{array}$ & $\begin{array}{l}\text { Namibia } \\
\text { Namibia } \\
\text { Namibia }\end{array}$ & $\begin{array}{l}\text { Kophobelemnon stelliferum } \\
\text { Kophobelemnon stelliferum } \\
\text { Kophobelemnon stelliferum, } \\
\text { Amphibelemnon namibiensis }\end{array}$ \\
\hline $\begin{array}{l}\text { PP-7 } \\
\text { P-43 } \\
\text { P-68 }\end{array}$ & $\begin{array}{c}6.7 .89 \\
13.7 .89 \\
19.7 .89\end{array}$ & $\begin{array}{l}24^{\circ} 12.0^{\prime} \mathrm{S}-14^{\circ} 4.0^{\prime} \mathrm{E} \\
28^{\circ} 50.0^{\prime} \mathrm{S}-14^{\circ} 24.0^{\prime} \mathrm{E} \\
23^{\circ} 19.0^{\prime} \mathrm{S}-13^{\circ} 5.0^{\prime} \mathrm{E}\end{array}$ & $\begin{array}{l}152 \\
458 \\
439\end{array}$ & $\begin{array}{l}\text { Namibia } \\
\text { South Africa } \\
\text { Namibia }\end{array}$ & $\begin{array}{l}\text { Kophobelemnon stelliferum } \\
\text { Halipteris africana } \\
\text { Pennatula inflata }\end{array}$ \\
\hline
\end{tabular}

area afford a unique opportunity to examine biodiversity in this region of biogeographic interest.

In addition to the upwelling that occurs, the southward flowing Angola Current and the northward flowing Benguela Current converge in the Namibian region.

The studies carried out to date in the framework of the EPAU programme have made significant contributions to existing knowledge of benthic fauna (see Macpherson, 1984; Uriz, 1988, Gili et al., 1989) and plankton (see Olivar and Fortuño, 1985; Pagès et al., 1992). These studies have revealed the special characteristics of the Namibia region together with its biological richness and high level of biodiversity.

The present study reports on the pennatulacean fauna (Cnidaria, Anthozoa) collected in the EPAU programme in the region off Namibia and Guinea Bissau. Pennatulaceans are one of the most common zoological groups in moderately deep and deep waters in all oceans but are still not sufficiently well known from a geographical point of view (Williams, 1995).

Only fifteen publications have previously considered West African pennatulaceans. These are by Broch (1910, 1914, 1958), Buchanan (1955), Dolfus (1938), López-González et al. (2000), Molander (1929), Pax and Müller (1954), Studer (1878), Tixier-Durivault $(1961,1963)$ and Williams $(1987$, 1989, 1990, 1992). The pennatulacean fauna of the west coast of Africa is poorly known, especially in the area off Namibia, one of the least well known areas in the South Atlantic (Williams, 1992). The present study adds to the previously-established knowledge of related interest: Grasshoff (1982a, $1982 b$ ), which dealt with pennatulacean taxa from the Bay of Biscay, and Grasshoff (1989), which dealt with those from the Strait of Gibraltar.

\section{MATERIAL AND METHODS}

The pennatulacean material studied in the present report is from nine cruises off the west coast of Africa, one of them in the Guinean Gulf, and the remainder in the Southeast Atlantic. The equipment used was a large commercial fisheries trawl. More than 350 specimens of 13 species (one of them here considered at the generic level only) were collected from 54 stations. These are as follows:

- 14 stations off Guinea Bissau coast, near Bissagos Islands, 25-256 m deep (cruise GUINEA BISSAU, December 1984-February 1985).

- 28 stations off southern Namibia, 145-849 m deep (cruises: BENGUELA V, 1983; BENGUELA VI, 1984; BENGUELA VII, 1984; BENGUELA VIII, 1985; BENGUELA XIII, 1988; and BENGUELA XV, 1989).

- 11 stations off northernmost South Africa (just south of the Orange River mouth) 91-1098 m deep (cruises: BENGUELA VI, 1984; BENGUELA VII, 1984; BENGUELA VIII, 1985; BENGUELA IX, 1986; and BENGUELA XI, 1987).

- 1 station on the Walvis Ridge (on Valdivia Bank, the shallowest part of the ridge), $1112 \mathrm{~m}$ deep (cruise BENGUELA VI, 1984).

The specimens collected from these cruises are deposited in the California Academy of Sciences (CASIZ), South African Museum (SAM) Cape Town, Instituto de Ciencias del Mar (ICM) of Barcelona, and Laboratorio de Biología Marina (LBM) of the University of Sevilla, Spain. Diagnostic descriptions included in this paper are from these specimens.

Some pennatulacean specimens from adjacent areas have been used for comparisons. These speci- 
mens are deposited in the following three institutions: the Nationaal Natuurhistorisch Museum, formerly the Rijksmuseum van Natuurlijke Historie (RMNH) of Leiden, the South African Museum (SAM) of Cape Town, and the Musée National d'Histoire Naturelle (MNHN) of Paris.

All material was preserved in $70 \%$ ethanol. Sclerites from different parts of the colonies were prepared for study by scanning electron microscope, and permanent mounts were made for observation by light microscope.

The list of stations including the different location features and the species collected is indicated in Table 1.

\section{ACCOUNT OF SPECIES COLLECTED}

\section{Veretillum cynomorium (Pallas, 1766)}

Material examined: LBM (ANT-112) Guinea Bissau: P-1, 6 colonies; LBM (ANT-113) Guinea Bissau: P-1, 1 col.; P-4, 1 col.; P-106, 2 cols.; P-114, 2 colonies; P-138, 2 colonies; ICM (GBN114) Guinea Bissau: P-2, 1 colony; ICM (GBN-111) Guinea Bissau: P-21, 14 colonies; ICM (GBN-114) Guinea Bissau: P-180, 3 colonies.

Diagnosis: Colonies elongated and cylindrical, preserved specimens up to $250 \mathrm{~mm}$ in length. Rachis $73 \%$ of colony length, peduncle $27 \%$ of colony length. Autozooids relatively large and distributed on the rachis in all directions. Siphonozooids in longitudinal rows on the rachis. Axis short. Sclerites of the rachis platelet, $0.08 \mathrm{~mm}$ in length. Sclerites of the peduncle similar to the rachis, $0.09 \mathrm{~mm}$ in length.

Remarks: All specimens examined are from off the coast of Guinea. However, this species has been reported from the Atlantic south of the Bay of Biscay, the Mediterranean, the south-west African coast (Kükenthal, 1915; Molander, 1929; Broch, 1958), and even a single locality reported from southern Mozambique, Indian Ocean (Tixier-Durivault, 1960). Williams (1990) reported the bathymetric distribution of this species to be between 13 and 91 $\mathrm{m}$. The colonies studied here were from 25 to $188 \mathrm{~m}$.

\section{Cavernularia kuekenthali}

López-González, Gili and Williams, 2000

Material examined: ZMH (C 11642) Guinea Bissau: P-2, 1 colony (Holotype); ZMH (C 11643) Guinea Bissau: P-21, 1 colony (Paratype); ZMH (C 11644) Guinea Bissau: P-2, 1 colony (Paratype); LBM (ANT-156) Guinea Bissau: P-2, 2 colonies; ICM (GBN-120) Guinea Bissau: 1 colony; CAS (111457) Guinea Bissau: P-23, 1 colony.
Diagnosis: (After López-González et al., 2000) Colonies elongate, clavate. Peduncle length about $39 \%$ of colony length. Rachis length about $61 \%$ of colony length. Rachis slightly expanded, distal terminus rounded. Autozooids more than 200, capable of complete retraction into rachis, irregularly arranged. Siphonozooids numerous and minute. Short axis present on base of rachis. Rachis surface sclerites stout rods $0.05-0.39 \mathrm{~mm}$. Rachis interior sclerites similar in shape and size to those of surface, densely represented. Peduncle surface sclerites oval $0.07-0.21 \mathrm{~mm}$, densely represented. Peduncle interior sclerites minute and oval $<0.01 \mathrm{~mm}$. Autozooids without sclerites in walls and pinnules. Colony colour cream white to grey in preserved specimens.

Remarks: This species has been recently described as part of a revision of some Cavernularia species from the eastern Atlantic and western Pacific Oceans (López-González et al., 2000). In that paper, additional material belonging to this species and previously deposited at the MNHN and ZMH was also re-examined. All known colonies of C. kuekenthali are from the Gulf of Guinea, from 5 to $32 \mathrm{~m}$ in depth. For additional details about the external and internal anatomy of this species see López-González et al. (2000).

\section{Amphibelemnon namibiensis}

López-González, Gili and Williams, 2000

Material examined: ZMH (C 11645) Benguela VIII: P-6, D-12,1 colony (Holotype); ZMH (C 11646) Benguela VIII: P-43, 2 colonies (Paratypes); ICM (GBN-126) Benguela V: P-32, 1 colony; LBM (ANT-128) Benguela VI: P-3, 6 colonies; LBM (ANT-153) Benguela VI: P-21, 17 colonies; ICM (GBN-154) Benguela VII: DP-71, 1 colony; LBM SAM (H4845) Benguela VII: DP-61, 1 colony; LBM (ANT-131) Benguela VIII: P-2, 8 colonies; LBM SAM (H4846) Benguela VIII: P-2, 2 colonies; LBM (ANT-127) Benguela VIII: P-6, D-12, 16 colonies; CAS (111458) Benguela VIII: P-6, D-12, 1 colony; LBM (ANT-130) Benguela VIII: P-13, 1 colony; LBM (ANT-129) Benguela VIII: P-16, D-311 colony; CAS (111459) Benguela VIII: P-43, 1 colony; LBM (ANT-123/124) Benguela XIII: P-9, 30 colonies, most in poor condition; LBM (ANT-122) Benguela XV: PP-6, 4 colonies; CAS (113255) Benguela XV: PP-6, 4 colonies; SAM (H4841) Benguela XV: PP6, 4 colonies; ICM (GBN-122) Benguela XV: PP-6, 22 colonies.

Diagnosis: (After López-González et al., 2000) Colonies elongate, clavate to nearly cylindrical. Peduncle length $50-54 \%$ of colony length. Rachis length $46-50 \%$ of colony length. Rachis slightly expanded, distal terminus rounded. Autozooids numerous (approximately 100 in number in a specimen $48 \mathrm{~mm}$ long), and relatively large, irregularly arranged, retractile into permanent spicular calyces. 
Calyces six to eight-toothed. Axis absent. Rachis surface sclerites spindle-shaped. Rachis interior sclerites absent. Peduncle surface sclerites rodshaped $0.12-0.30 \mathrm{~mm}$. Peduncle interior sclerites minute ovals. Autozooids with small rod-shaped sclerites in pinnules, sclerites in walls absent. Calyces with rod and spindle-shaped sclerites, mostly three-flanged at each end. Colony colour creamwhite to dark grey in preserved specimens.

Remarks: This pennatulacean is the type species of the recently described genus Amphibelemnon (López-González et al., 2000). These authors also re-examined additional material previously deposited at the SAM. This species is known only from off the Namibian coast, between 91 and 304 m depth. For additional details about the external and internal anatomy of this species see López-González et al. (2000).

Kophobelemnon stelliferum (Müller, 1776)

Material examined: ICM (GBN-91) Benguela-V: P-26, 4 colonies; ICM (GBN-92) Benguela-V: P-16, 2 colonies; ICM (GBN-93) Benguela-V: P-21, 1 colony; ICM (GBN-141) Benguela-XV: PP-4, 31 colonies; ICM (GBN-148) Benguela-XV: PP-4, 22 colonies; LBM (ANT-148) Benguela-XV: PP-4, 2 colonies; ICM (GBN-142) Benguela-XV: PP-5, 18 c colonies.; ICM (GBN-140) BenguelaXV: PP-5, 14 colonies; ICM (GBN-138) Benguela-XV: PP-6, 14 colonies; ICM (GBN-139) Benguela-XV: PP-6, 15 colonies; ICM (GBN-137) Benguela-XV: PP-7, 15 colonies; ICM (GBN-147) Benguela-XV: PP-7; 13 colonies.

Diagnosis: Colonies elongate, cylindrical and clavate, gradually widening distally, up to $290 \mathrm{~mm}$ in length. Rachis $64 \%$ of colony length, peduncle $36 \%$ of colony length. The whole colony is very rigid because of the high density of sclerites. Autozooids relatively large and distributed on the rachis in two longitudinal rows. Siphonozooids with two-toothed calyces Axis thin. Sclerites of the rachis three-flanged spindles with tuberculate ends, $0.21-0.57 \mathrm{~mm}$ in length. Sclerites of the peduncle rods of similar shape to those of the rachis, $0.10-0.21 \mathrm{~mm}$ in length.

Remarks: Nine species of Kophobelemnon have been considered valid in the last synopses of the living genera of Pennatulacea (Williams, 1995). Four Kophobelemnom species are exclusive to Indo-Pacific areas, two are from Atlantic plus Pacific localities, one from the Caribbean, one from the Mediterranean, and the ninth from the Antarctic Peninsula (Kükenthal, 1915; Keller, et al., 1975; Parternak, 1975; Williams, 1990). The known bathymetric range of the genus is very wide, between $36-4400 \mathrm{~m}$.

\section{Anthoptilum grandiflorum (Verrill, 1879)}

Material examined: ICM (GBN-93) Benguela-V: P-21, 1 colony; LBM (ANT-94) Benguela-V: P-19, 5 colonies; ICM (GBN-104) Benguela-VII: P-130, 1 colony.

Diagnosis: Colonies elongate, whip-like, up to $220 \mathrm{~mm}$ in length. Rachis $73 \%$ of colony length, peduncle $27 \%$ of colony length. Autozooids mainly arranged in oblique rows of 4-5 polyps, in two longitudinal rows on the rachis, fused at bases, and relatively large. Siphonozooids minute and numerous. Sclerites absent, except for minute ovals in the inner region of peduncle.

Remarks: Anthoptilum grandiflorum has been recorded from several western, eastern and southern Atlantic localities, between $238-2500 \mathrm{~m}$ in depth, and was recently considered cosmopolitan (Williams, 1990, 1995).

\section{Distichoptilum gracile Verrill, 1882}

Material examined: LBM (ANT-90) Benguela-VI: BB3, F-44, 3 colonies.

Diagnosis: Colonies elongate, whip-like, up to $160 \mathrm{~mm}$ in length. Rachis $69 \%$ of colony length, peduncle $31 \%$ of colony length. Autozooids arranged in two longitudinal series, facing upward, adaxial side of calyces appressed to lateral margin of the rachis. Siphonozooids contained on the rachis, two per autozooid. Sclerites of the rachis are threeflanged spindles, 0.38-0.90 $\mu \mathrm{m}$ in length. Sclerites of the peduncle are three-flanged rods. Preserved colonies have orange calyces and whitish coenenchyme.

Remarks: The single variable valid species of this genus has a cosmopolitan distribution, with a wide bathymetric range of 793-4300 m (Kükenthal, 1915; Williams, 1990, 1995). This record confirms the presence of $D$. gracile in southern African Atlantic waters, reported by Williams (1990).

Virgularia mirabilis (Linné, 1866)

Material examined: LBM (ANT-99) Guinea-Bissau: P-149, 1 fragment.

Diagnosis: The single fragment studied is 130 $\mathrm{mm}$ in length. Rachis slender, peduncle missing. Autozooids fused at the base forming short polyp leaves. These are more-or-less paired, each with 6-8 
polyps retractile into fleshy calyces with smooth distal border. Siphonozooids difficult to observe, contained on the rachis. Sclerites absent. The fragment of the rachis is cream in colour.

Remarks: Virgularia mirabilis is widely distributed in the Atlantic Ocean, from Arctic waters to southern Africa, including the western and eastern Atlantic coasts and Mediterranean Sea (Kükenthal, 1915; Manuel, 1981; Tixier-Durivault, 1961, 1963; Williams, 1990). Moreover, this species was reported by Tixier-Durivaul and d'Hondt (1973) in Madagascar. The known bathymetric range for this species is $9-400 \mathrm{~m}$.

\section{Virgularia tuberculata Marshall, 1883}

Material examined: LBM (ANT-98) Benguela-IX: P-29, 1 colony; LBM (ANT-100) Benguela-VIII: P-52/D-103, 1 colony.

Diagnosis: Colonies elongate, preserved specimens up to $180 \mathrm{~mm}$ in length. Rachis slender, $64 \%$ of colony length, peduncle $36 \%$ of colony length. Autozooids fused at the base forming short polyp leaves. These are positioned alternately, with 5-6 polyps per polyp leaf. Autozooids retractile into fleshy calyces with slightly tuberculate distal border. Siphonozooids difficult to observe, contained on the rachis. Sclerites absent. The colonies are brownish in colour.

Remarks: This species is easily distinguished from the other Virgularia species by having a small number of autozooids per polyp leaf (3-6) and small tubercles on the distal borders of the fleshy calyces. Virgularia tuberculata is a well known pennatulacean species from North Atlantic and Arctic waters (see Kükenthal, 1915). However, there are some reports (Tixier-Durivault, 1961, 1963) of the species in different localities from off the western African coast, near Gabon and Angola, between 35 and $40 \mathrm{~m}$ in depth. The present study extends the known geographical distribution range to Namibia, and the known bathymetrical range to $439 \mathrm{~m}$.
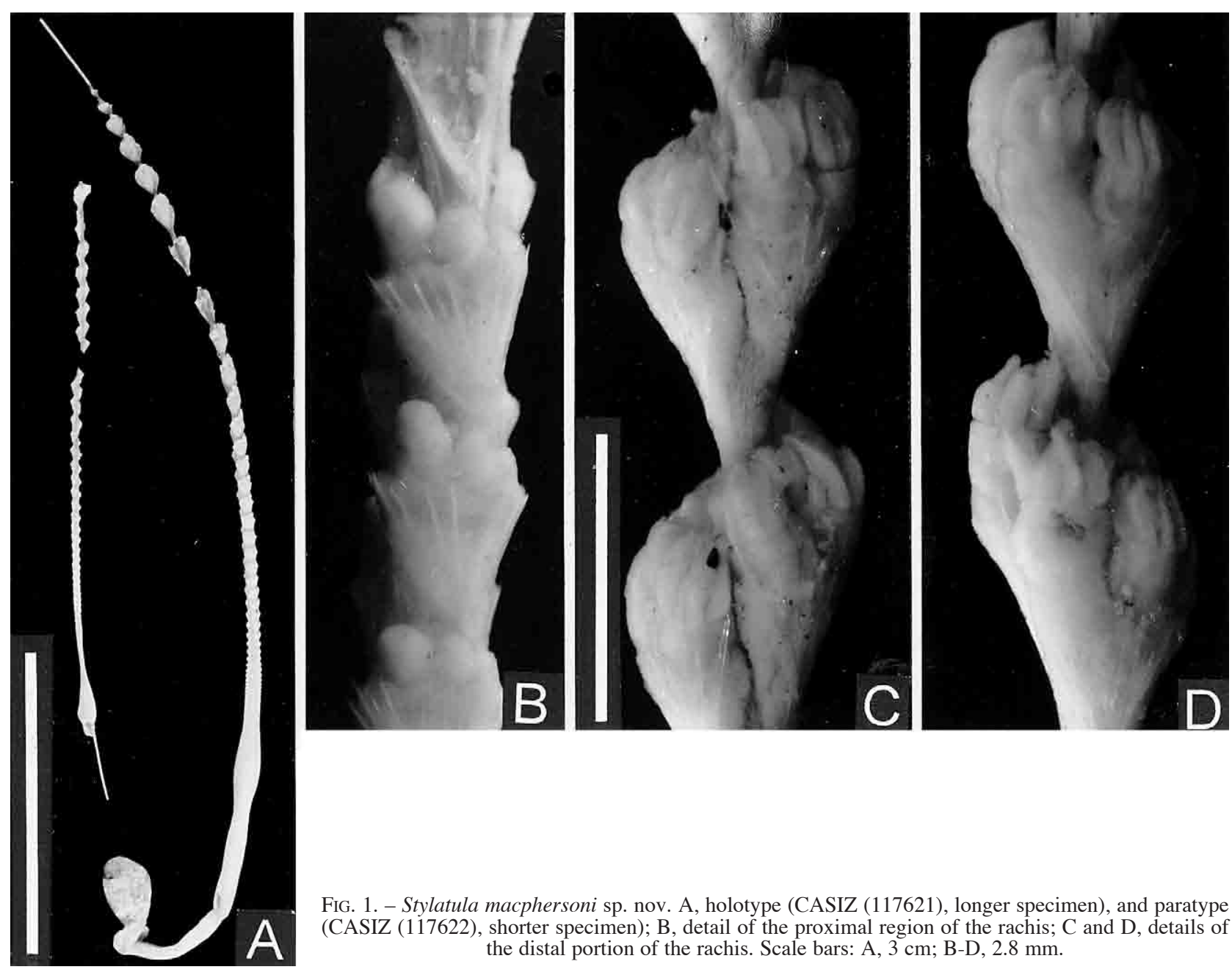

FIG. 1. - Stylatula macphersoni sp. nov. A, holotype (CASIZ (117621), longer specimen), and paratype (CASIZ (117622), shorter specimen); B, detail of the proximal region of the rachis; C and D, details of the distal portion of the rachis. Scale bars: A, $3 \mathrm{~cm}$; B-D, $2.8 \mathrm{~mm}$. 
Stylatula macphersoni sp. nov.

(Fig. 1-4)

Material examined: Holotype, CASIZ (117621), Benguela-VII: DP56,1 colony (fragmented into two parts) $115 \mathrm{~mm}$ in length. Paratype, CASIZ (117622), Benguela-XIII: P-54, 1 colony broken into two parts and lacking the proximal part of the peduncle, $60 \mathrm{~mm}$ in length. Material for comparison: Stylatula elegans (Danielssen, 1860), RMNH(02763), Tromdheimfjord, Norway, 1965, 1 colony in three fragments (sclerites illustrated in Fig. 5). LBM (ANT-200) BIOICE stn 719, sample no. 2829, 25-8-95, 63041'66.7'” 16 $6^{\circ} 84^{\prime} 08.33^{\prime \prime} \mathrm{W}$, 277-283 m depth, 10 colonies.

Diagnosis: Colonies slender, up to 6 pairs of polyp leaves in $20 \mathrm{~mm}$ of rachis. Three autozooids in each leaf arranged in a single row. Autozooids with free body walls. Supporting armature with 7-11 large needles $1.40-2.20 \mathrm{~mm}$ long and numerous smaller needles, 0.23-0.73 mm long. Sclerites of the body walls are flanged rods of two size categories, $0.18-0.34 \mathrm{~mm}$ long and $0.10-0.19 \mathrm{~mm}$ long. Sclerites of the tentacles are slightly flanged rods of two size categories, $0.08-0.13 \mathrm{~mm}$ long and $0.07-0.10$ $\mathrm{mm}$ long. Siphonozooids placed on the rachis, in the leaf axils. Axis stiff, rounded in cross section.

External morphology: Colonies examined up to $115 \mathrm{~mm}$ long, very slender, but moderately rigid and straight, brittle. The rachis is $72-42 \mathrm{~mm}$ long (63\% of the colony length) and $2.5 \mathrm{~mm}$ in maximum width, while the peduncle is $43 \mathrm{~mm}$ in length
(37\% of colony length) and $3 \mathrm{~mm}$ in width (the peduncle was broken in the paratype). The rachis with polyp leaves projecting upward, adnate, up to 6 pairs in $2 \mathrm{~cm}$ of rachis. Pairs of polyp leaves small and not crowded distally, and more crowded on the lower part of the rachis. Polyp leaves placed alternately in the lower part of the rachis, and more-orless oppositely in the upper part. The large needles of the supporting armature slightly reaching the fused basal part of the autozooids, but never covering the free bodies. Three autozooids per leaf, increasing slightly in size from the inner to the outer polyps. Autozooid bodies are cylindrical, not fused laterally. The tentacles with one row of 12-14 pinnules on each side. Lateral body walls of the autozooids and aboral side of tentacles with visible sclerites. Peduncle elongate with a moderate bulb on the distal mid-portion.

Sclerites: Supporting armature of polyp leaves with 7-11 large needles 1.40-2.20 mm long, and numerous smaller needles, $0.23-0.73 \mathrm{~mm}$ long. Sclerites of the body walls are three-flanged rods of two size categories, $0.18-0.34 \mathrm{~mm}$ long and 0.10 $0.19 \mathrm{~mm}$ long. Sclerites of the tentacles are slightly three-flanged rods of two size categories, 0.08-0.13 $\mathrm{mm}$ long and 0.07-0.10 $\mathrm{mm}$ long. Peduncle without sclerites.
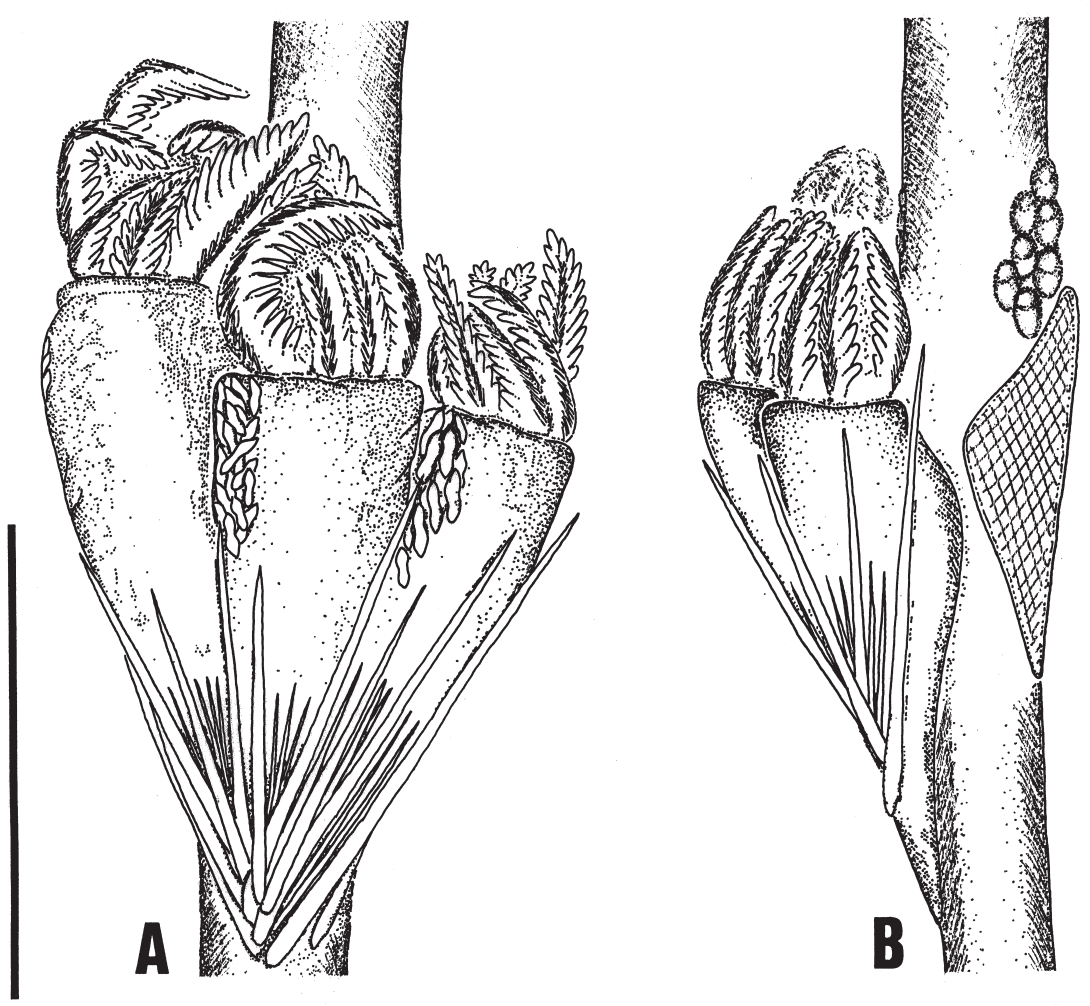

FIG. 2. - Stylatula macphersoni sp. nov. CASIZ (117621). A and B, holotype. Scale bar: 2 mm. 


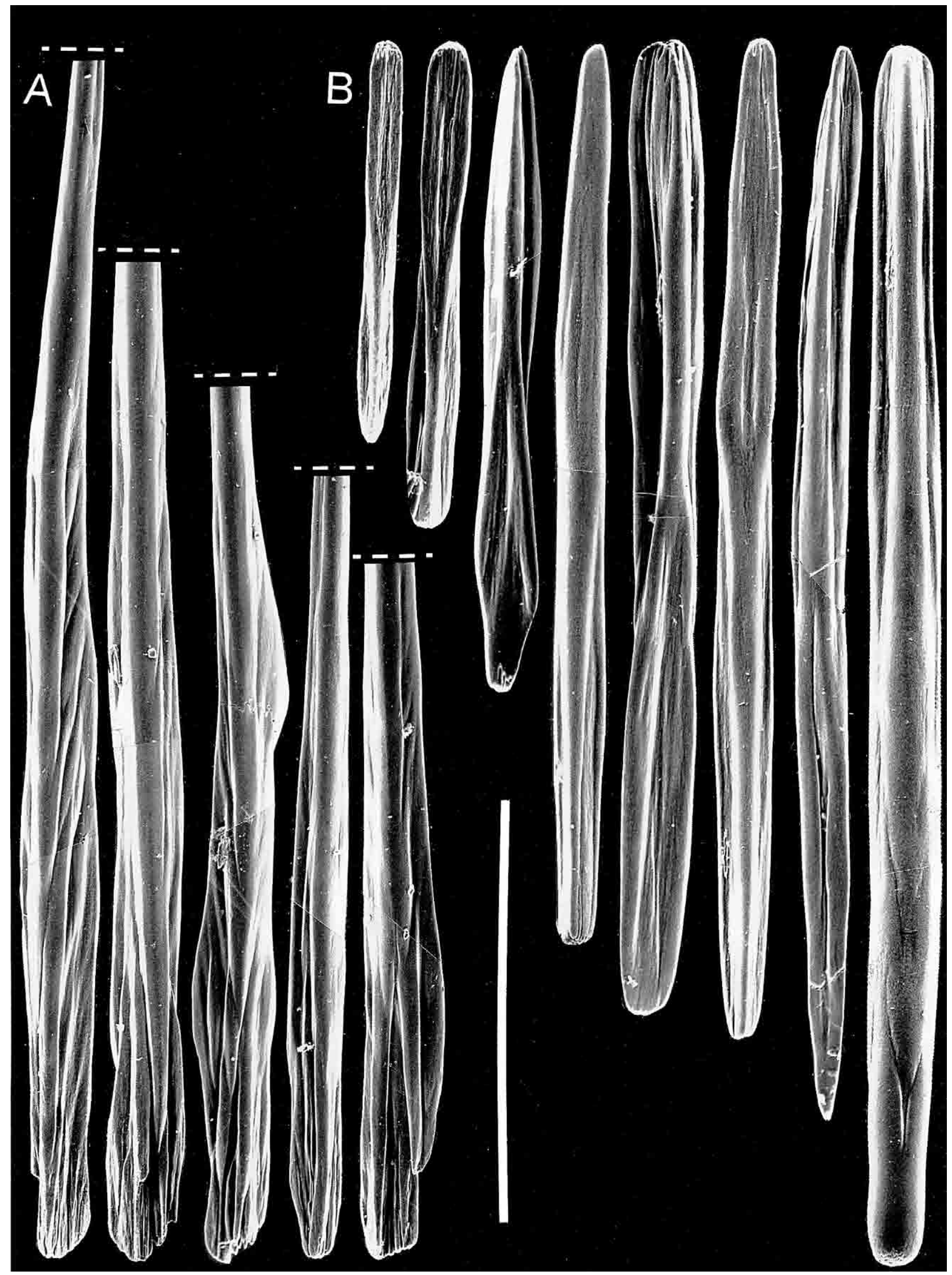

FIG. 3. - Stylatula macphersoni sp. nov. Holotype CASIZ (117621). A, proximal portions of large needles from supporting armature; B, second category of needles from supporting plates. Scale bars: A, $500 \mu \mathrm{m} ; \mathrm{B}, 1000 \mu \mathrm{m}$. 


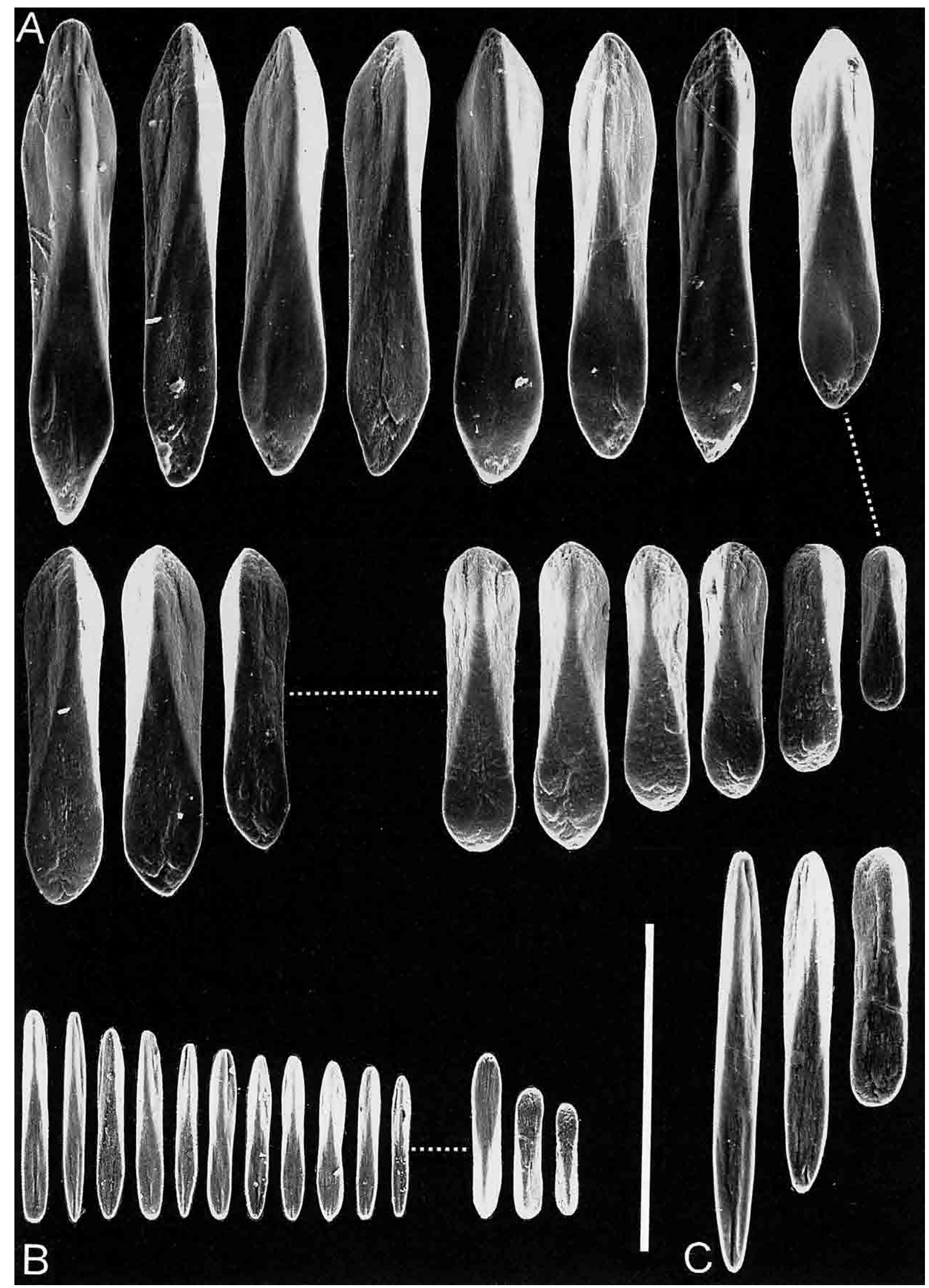

FIG. 4. - Stylatula macphersoni sp. nov. Holotype CASIZ (117621). A, sclerites from the body walls of autozooids in two size and shape categories; B, sclerites from the aboral side of tentacles in two shape categories; C, the same as B enlarged. Scale bars: A and B $200 \mu \mathrm{m}$; C, $100 \mu \mathrm{m}$. 


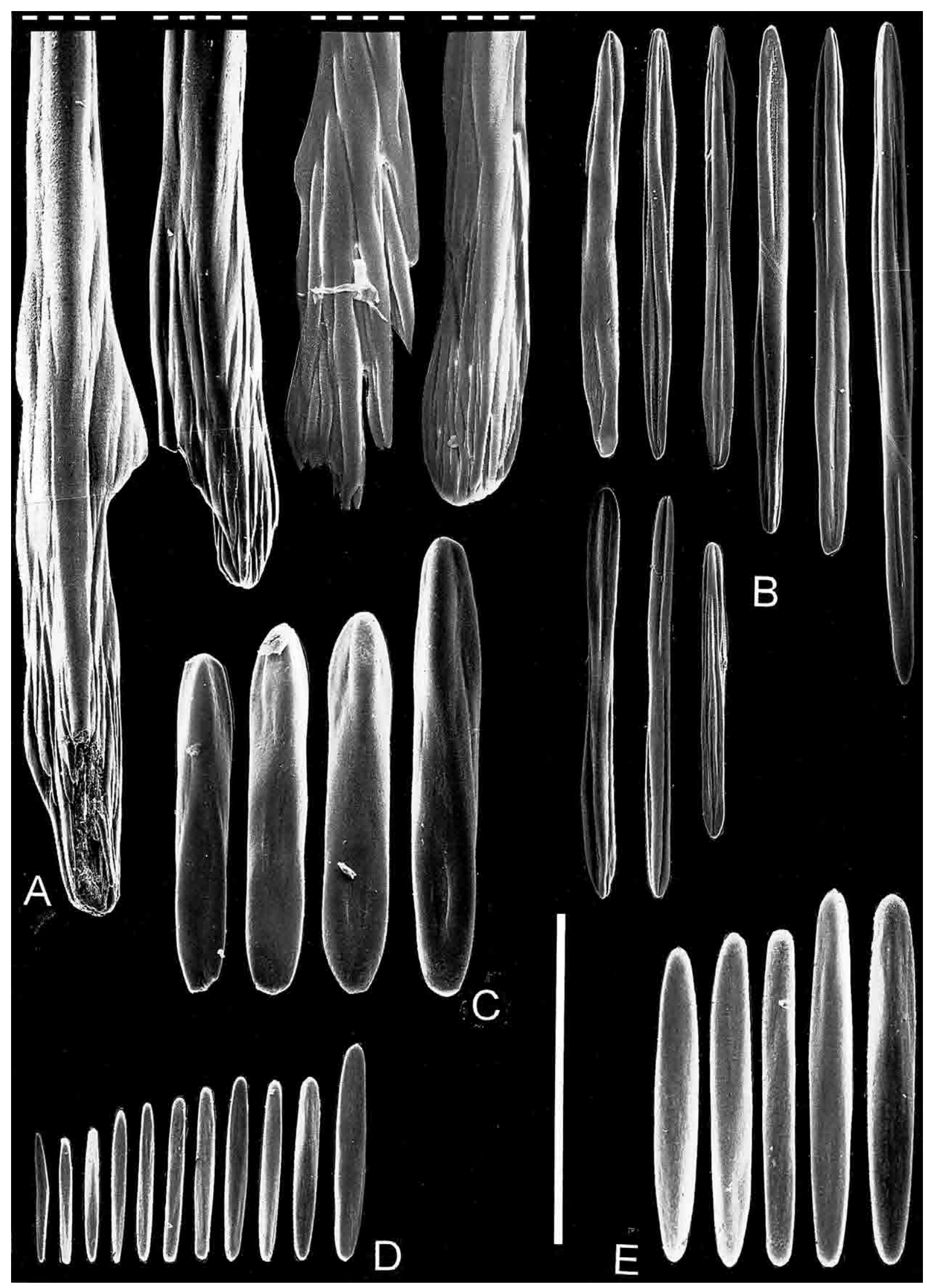

FIG. 5. - Stylatula elegans (Danielssen). RMNH (02763). A, proximal portions of large needles from supporting armature; B, second category of needles from supporting armature; C, sclerites from the body walls of autozooids; D, sclerites from the aboral side of tentacles; E, the same as D enlarged. Scale bars: A and B, $400 \mu \mathrm{m} ; \mathrm{C}$ and D, $200 \mu \mathrm{m} ; \mathrm{E}, 100 \mu \mathrm{m}$. 
Colour: Preserved specimens are white to grey in colour.

Distribution: The species is currently known only from off the Namibian coast, between 245 and $318 \mathrm{~m}$ depth.

Etymology: The specific epithet is dedicated to Dr. Enrique Macpherson, head of the Spanish Programme "The study of Austral African Fisheries" for making available the octocoral collections from Benguela cruises in South Africa and Namibia, where the new species of Stylatula was found, and specially for his relevant contribution to the knowledge of Namibian marine biodiversity.

Remarks: Kükenthal (1915: 68) recognised six valid species of the virgulariid genus Stylatula Verrill, 1868: S. elegans (Danielssen, 1860), S. elongata Verrill, 1864, S. gracilis Verrill, 1864, S. darwinii Kölliker, 1870; S. kinbergii Kölliker, 1870, and S. lacazi Kölliker, 1870. Two species, S. antillarum Kölliker, 1870 and S. brasiliensis (Gray, 1870), were considered as doubtful. However, Bayer (1959: 38; 1961: 308) regarded both species as valid, and described a new species, S. diadema, based on the original position of the siphonozooids. In his revision of the living genera of sea pens, Williams (1995: 122-123) considered all nine species as valid. Recently, Zamponi and Pérez (1996) described S. polyzoidea from the southwestern Atlantic. However, more information and illustrations of the morphology of the autozooids and sclerites of this species are desirable.

Stylatula diadema is clearly distinguished from the other Stylatula species listed above because it has siphonozooids placed in rosettes on the lower ventral surface of the polyp leaves, while in the other species the siphonozooids are placed on the rachis, in the polyp leaf axils (Bayer, 1961).

Within the remaining nine Stylatula species, only S. elegans, S. brasiliensis, and S. macphersoni sp. nov. have less than 15 autozooids per polyp leaf (Kükenthal, 1915; Bayer, 1961). However, S. brasiliensis is easily distinguished from the other two species by the fact that the autozooids of each polyp leaf are fused together, except for a short distal calycular part, while in $S$. elegans and $S$. macphersoni sp. nov., the body walls of autozooids are distinctly separate, and joined only in their lowest parts (Kükenthal, 1915; present account) (Figs. $1 \mathrm{C}-\mathrm{D}$, and 2A-B).
Stylatula macphersoni sp. nov. is closest to the well-known northern Altlantic species S. elegans. However, the species are quite different. In S. elegans the sclerites of the body of the autozooids are slightly elongate rods, while in S. macphersoni sp. nov. these sclerites are always present as robust flanged rods (see Figs. 4A, and 5C). Moreover, the sclerites of the aboral side of the tentacles, abundant in both species, have the same difference in shape as those of the body wall autozooids (see Fig. 4B-C, and Fig. 5D-E). The sclerites of the supporting plates are also different between Stylatula elegans and S. macphersoni sp. nov. In the former species, the principal needles are much more robust and larger than those of $S$. macphersoni sp. nov. (see Figs. 3A, and 5A). The smaller needles of the supporting plates are similar in both species (see Figs. 3B, and 5B). The number of autozooids in each polyp leaf is 3-7 in S. elegans (Bayer, 1961; present account), while in $S$. macphersoni sp. nov. it is only 3 autozooids in the two colonies examined. Furthermore, the number of pairs of polyp leaves in $2 \mathrm{~cm}$ of rachis is 3-4 in S. elegans, whereas in S. macphersoni sp. nov. it is up to 6. Finally, S. elegans is only known from Northern Atlantic waters (Kükenthal, 1915; Williams, 1990), although $S$. macphersoni sp. nov. is known only from off the Namibian coast.

\section{Halipteris africana (Studer, 1879)}

Material examined: ICM (GBN-95) Benguela-VI: BB-11: 1 colony; ICM (GBN-119) Benguela-VI: P-54, 1 colony; P-55, 1 colony + 1 fragment; P-73, 5 colonies; ICM (GBN-134) Benguela-VI: P-73, 1 colony; ICM (GBN-104) Benguela-VII: P-130, 1 colony; ICM (GBN-117) Benguela-VII: P-36, 1 colony; ICM (GBN-116) Benguela-VIII: P-29, 10 colonies; LBM (ANT-103) Benguela-VIII: P-29, 1 colony; ICM (GBN-102) Benguela-XIII: P-46, 1 colony; LBM (ANT-144) Benguela-XV: P-43, 1 colony; SAM (H4847) Benguela-XV: P-43, 1 colony.

Diagnosis: Colonies elongate, whip-like, preserved specimens up to ca. $1000 \mathrm{~mm}$ in length. Rachis $75 \%$ of colony length, and peduncle $25 \%$. Axis rounded in section, $2-3 \mathrm{~mm}$ in diameter. Autozooids arranged in oblique rows of 2-6 polyps, in two longitudinal series on the rachis. Calyces of autozooids sometimes with distinct teeth. Autozooids fused only at bases. Aboral side of autozooids, tentacles, and calyces with three-flanged spindles, $0.08-0.16$ and $0.38-1.04 \mathrm{~mm}$ long respectively. Peduncle with minute rods, 0.04-0.10 $\mu \mathrm{m}$ long. Siphonozooids minute, on the rachis, among the autozooids ridges.

Remarks: The present report confirms the presence of this species off the Namibian and South African coasts, reported by Williams (1990). The 
species is present in the southeastern Atlantic, from the Senegal-Guinea coast to South Africa. The systematic position of this species was discussed by Williams (1990).

\section{Pennatula rubra (Ellis, 1764)}

Material examined: LBM (ANT-115) Guinea Bissau: P-110, 1 colony; P-117, 1 colony.

Diagnosis: Colonies bilateral, up to $118 \mathrm{~mm}$ in length, with 29-33 polyp leaves on the rachis. Rachis is $63 \%$ of the colony length, and has a narrow naked dorsal tract, up to $78 \mathrm{~mm}$ long. Peduncle $37 \%$ of the colony length, with a distinct medial bulb. Autozooids 39-45 per polyp leaf placed in 1-2 rows. Autozooid calyces with 4-8 marginal teeth. Mesozooids on the dorsal region of the rachis and on the basal dorsal region of the polyp leaves (only one or two mesozooids). Siphonozooids on the rachis dorsally, and between the polyp leaves ventrally. Sclerites are usually three-flanged spindles, minute ovals in the interior of peduncle.

Remarks: Pennatula rubra was considered a Mediterranean species by Kükenthal (1915). However, some specimens collected from off West Africa have been reported by different authors. Broch (1958) cited the species from the Portuguese coast near the Strait of Gibraltar to Angola, the latter being the southernmost known location for this species. Tixier-Durivault (1963) reported the presence of $P$. rubra off Guinea and Sierra Leone, and Patriti (1970) off Agadir. Recently, this species has been collected from Mediterranean and Atlantic sides of the Strait of Gibraltar (López-González, 1993).

Pennatula inflata Kükenthal, 1910

Material examined: ICM (GBN-105) Benguela-VI: P-12, 1 colony; P-41, 2 colonies; P-54, 2 colonies; ICM (GBN-107) Benguela-VI: P-59, 7 colonies; ICM (GBN-118) Benguela-VI: P-76, 4 colonies; ICM (GBN-117) Benguela-VII: P-36, 9 colonies; ICM (GBN-104) Benguela-VII: P-130, 1 colony; ICM (GBN-106) Benguela-VIII: P29, 3 colonies; ICM (GBN-108) Benguela-VIII: P-67, 3 colonies; ICM (GBN-133) Benguela-XI: P-37, 1 colony (in bad conditions); ICM (GBN-102) Benguela-XIII: P-46, 2 colonies; LBM (ANT149) Benguela-XV: P-68, 2 colonies.

Diagnosis: Colonies bilateral, up to $275 \mathrm{~mm}$ in length, with 29-31 polyp leaves on the rachis. Rachis is $70 \%$ of the colony length. Rachis with wide naked dorsal tract up to $13 \mathrm{~mm}$ long. Peduncle $30 \%$ of the colony length, with a distinct medial bulb. Autozooids 50-54 per polyp leaf placed in 1-2 rows. Autozooid calyces with 8 marginal teeth.
Mesozooids on the basal dorsal margin of the polyp leaves and on two narrow longitudinal bands along the dorsal rachis. Siphonozooids on the rachis, between the polyp leaves. Sclerites are usually three-flanged spindles, minute ovals in the interior of the peduncle.

Remarks: This species, originally described from off Somalia, was reported for the first time from the west South African coast by Tixier-Durivault (1954, as Pennatula phosphorea), and recently reported from the south Namibian coast by Williams (1990). These three specimens were the first records of $P$. inflata in the Atlantic Ocean (Tixier-Durivault, 1954) and two additional ones were collected in Lambert's Bay (326'S 18¹8'E) (Williams, 1990). The present account, based on a larger number of colonies, 35 in total, confirms the distribution of this species along the west African coast, and extends its known range north to off Walvis Bay (23 $8^{\circ}$ 'S$\left.13^{\circ} 5.6^{\prime} \mathrm{E}\right)$.

\section{Pteroeides sp.}

Material examined: LBM (ANT-135) Guinea Bissau: P-96, 2 colonies; P-207, 1 colony.

Remarks: Three colonies belonging unquestionably to the genus Pteroeides were collected from the Guinea-Bissau cruise. However, according to Williams (1990:107) this genus is in need of revision. The study of the type material of the over 87 species reported in the literature (if they are still available) is necessary to recognise an unknown number of valid species (at least 25 after Williams, 1995). We prefer to identify this material only at a generic level, as more information about the species of this genus from the African Atlantic coast is needed.

\section{ZOOGEOGRAPHY}

Williams (1992) provided a biogeographical analysis of the southern African octocoral fauna, including the Pennatulacea. The distribution of this fauna extends along part of the Atlantic coast of Africa (Williams, 1992: Figs.1, 2, 5). Williams (1999) listed literature citations relevant to the biogeography of the Pennatulacea, as well as taxa inhabiting the eastern Atlantic.

The West African coast is defined here as the region between Tangier (Morocco) in the north and 
Cape Point (Cape of Good Hope, South Africa) in the south (Fig. 6), and is synonymous with the African Atlantic coast.

The West African pennatulacean fauna can be divided into three geographic regions largely associated with the prevailing coastal currents (Fig. 6). The cold water Canary Branch of the North-Eastern Atlantic Current flows southward along the coasts of the Iberian Peninsula and the western bulge of Africa as far south as Liberia. The warmer nearequatorial Guinea Current flows eastward from Liberia to Gabon, while the cold water Benguela Current sweeps northward from Cape Point to Angola.

Zoogeographic regions, defined here for the purposes of the present study are as follows:

Northern Atlantic - widespread in the Arctic and/or North Atlantic; found in the Atlantic outside of the Canary region.

Canary - including the southern Bay of Biscay, Iberian Peninsula, western Mediterranean Sea, western Canary Islands, and along the northwest African coast to Liberia.

Gulf of Guinea - along the African coast between Liberia in the west and Gabon in the east.

Benguela - along the southwest African coast from Angola in the north to Cape Point in the south.

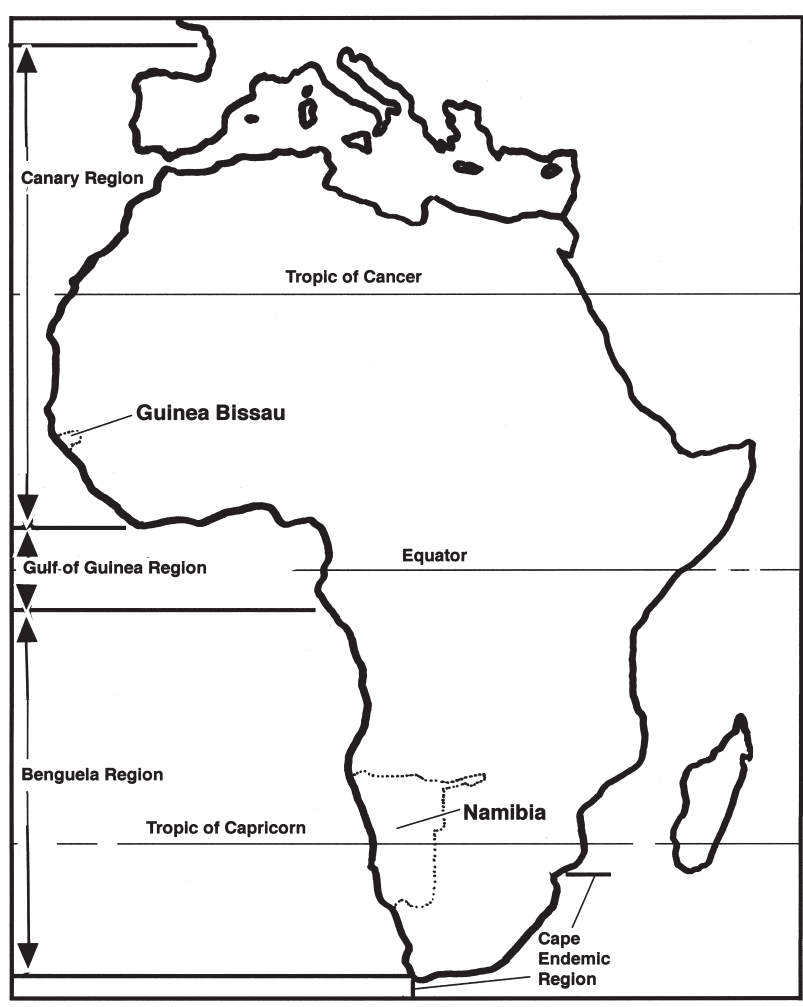

FIG. 6. - Map of Africa showing various regions of western Africa.
TABLE 2. - Biogeographic and bathymetric affinities of the West African pennatulacean fauna: B - Benguela; C - Canary; CE - Cape Endemic; G - Gulf of Guinea; NA - North Atlantic; W - Widespread.

\begin{tabular}{lcc}
\hline Species & $\begin{array}{c}\text { Zoogeographic } \\
\text { Region }\end{array}$ & $\begin{array}{c}\text { Depth Range } \\
(\mathrm{m})\end{array}$ \\
\hline Actinoptillum molle & $\mathrm{CE}$ & $12-333$ \\
Anthoptilum grandiflorum & $\mathrm{W}$ & $238-2500$ \\
Amphibelemnon namibiensis & $\mathrm{B}$ & $91-304$ \\
Cavernularia mirifica & $\mathrm{C}$ & $18-89$ \\
Cavernularia kuekenthali & $\mathrm{G}$ & $5-32$ \\
Cavernularia pusilla & $\mathrm{C}$ & $65-120$ \\
Crassophyllum cristatum & $\mathrm{B}$ & $40-650$ \\
Distichoptilum gracile & $\mathrm{W}$ & $650-4300$ \\
Funiculina quadrangularis & $\mathrm{W}$ & $60-2600$ \\
Halipteris africana & $\mathrm{C} / \mathrm{G} / \mathrm{B}$ & $459-659$ \\
Kophobelemnon stelliferum & $\mathrm{W}$ & $400-1108$ \\
Pennatula inflata & $\mathrm{W}$ & $457-741$ \\
Pennatula rubra & $\mathrm{C}$ & $50-109$ \\
Pteroeides hirsutus & $\mathrm{G}$ & 78 \\
Pteroeides morbosus & $\mathrm{G}$ & 50 \\
Pteroeides spinosum & $\mathrm{C}$ & $30-280$ \\
Scleroptilum grandiflorum & $\mathrm{W}$ & $500-4200$ \\
Stylatula macphersoni sp. nov. & $\mathrm{B}$ & $245-318$ \\
Umbellula lindahli & $\mathrm{W}$ & $230-6100$ \\
Umbellula thomsoni & $\mathrm{W}$ & $1300-6200$ \\
Veretillum cynomorium & $\mathrm{C}$ & $13-91$ \\
Virgularia mirabilis & $\mathrm{W}$ & $9-400$ \\
Virgularia schultzei & $\mathrm{CE}$ & $0-222$ \\
Virgularia tuberculata & $\mathrm{NA} / \mathrm{G} / \mathrm{B}$ & $75-1050$ \\
& & \\
\hline & &
\end{tabular}

Cape Endemic - the coastal region of the Cape Province and Natal, South Africa (delimited by Williams, 1992: 361).

Widespread - scattered distribution; taxa found in various parts of the world's seas; widespread to nearly cosmopolitan.

\section{Analysis}

The data in Table 2, show that the shallow water biogeographic affinities of western Africa can be divided into three components:

(1) West African [Canary $22.22 \%$ + Gulf of Guinea $14.81 \%$ + Benguela $18.52 \%$ ], representing $55.5 \%$ of the fauna;

(2) North Atlantic [representing more widespread Atlantic taxa, $3.7 \%$ of the fauna];

(3) Cape Endemic [representing the southern African region, $7.4 \%$ of the fauna].

The North Atlantic and Canary regions can be viewed as cold water boreal, the Gulf of Guinea region as tropical, the Benguela region as cold water austral, and the Cape Endemic as primarily warm water temperate.

These shallow water taxa account for $66.6 \%$ of the fauna. The remainder $(33.3 \%)$ is comprised of widespread faunal taxa elements. These are species with ranges that extend outside of the Atlantic 


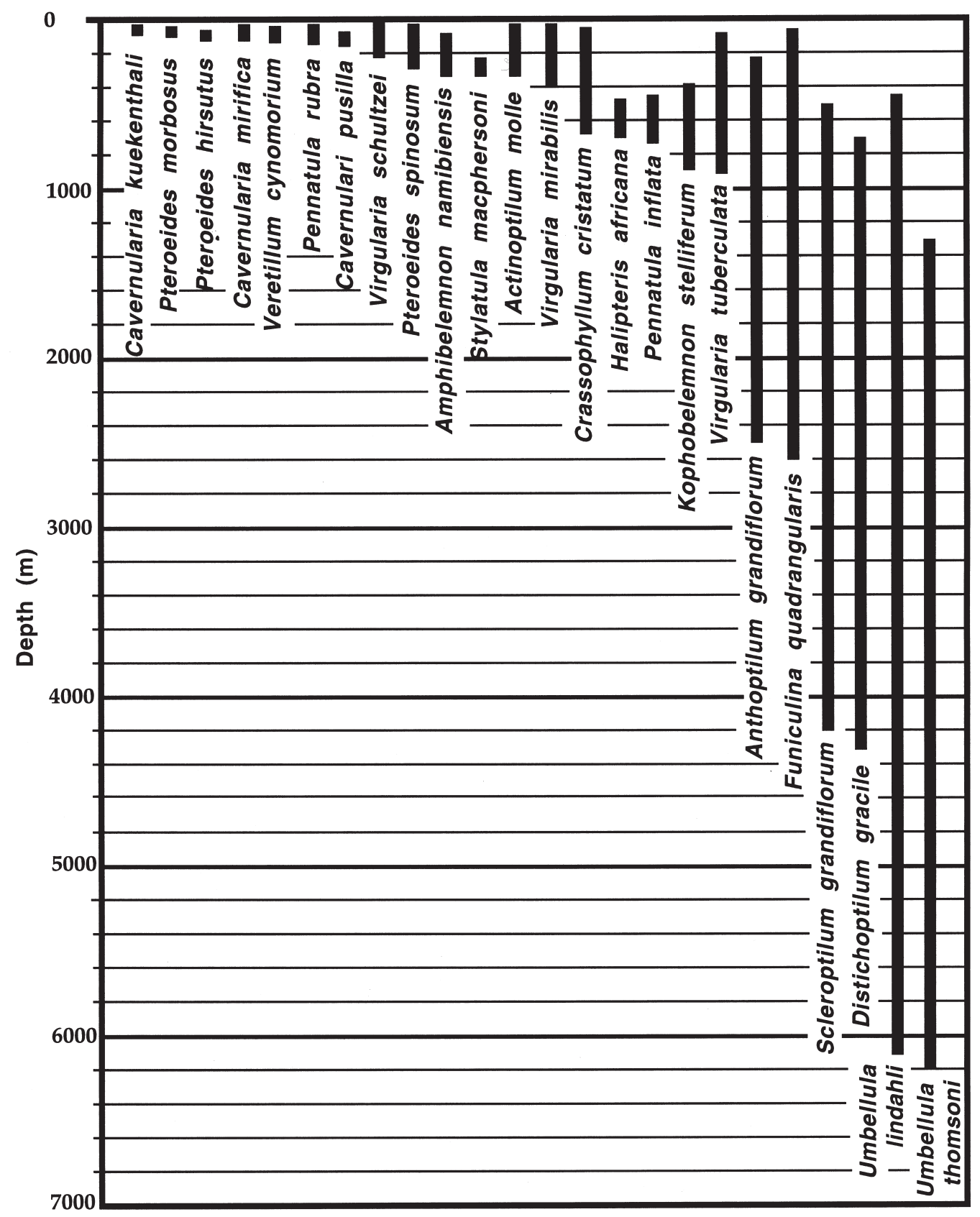

FIG. 7. - Chart of bathymetric distributions for pennatulacean taxa represented in the West African fauna. Depth ranges are those recorded for the entire geographic range from each species.

Ocean, ranging from those with relatively limited distributions to nearly cosmopolitan ones. These widespread taxa are species that have deep water bathymetric distributions (Fig. 7). In the Octocorallia, taxa with limited geographic ranges (endemics) tend to inhabit shallow waters of coastal regions, while many of those with widespread to cosmopolitan distributions inhabit deeper waters of the continental slope to abyssal plains (Williams, 1992).

\section{ACKNOWLEDGMENTS}

We thank the following individuals and institutions for providing material on loan for examination: Drs. Wim Vervoort and Koos den Hartog (Nationaal Natuurhistorisch Museum in Leiden), Mme. Marie José d'Hondt (Musée National d'Histoire Naturelle in Paris), and Liz Hoenson and Michelle van der Merwe (South African Museum, Cape Town). We want to express our gratitude to Dr. Francesc Pagès 
for supplying us material collected during the Guinea Bissau cruise on the fishing vessel M/P "Lulu". Many thanks also to all participants to the Benguela cruises for their careful collection of benthic material and to Dr. Enrique Macpherson, head of the "Estudio de las Pesquerías del África Austral (EPAU)" project which partially support this work. We are grateful to Ms. Asunción Fernández, staff of the Microscopical Service of the University of Seville for providing useful assistance in making the SEM photographs. Partial financial support for this work was provided by the "Fauna Ibérica IV" project (PB95-0235). Part of the present work was carried out during a visit of one of us (PJL-G) to the California Academy of Sciences, San Francisco. This visit was supported by the "Dirección General de Universidades, Junta de Andalucía". Part of the material of $S$. elegans consulted in this paper was provided by the BIOICE project. We express our gratitude to Drs Gudmundur Vidir, Gudmundur Gudmundsson, and the staffs of the BIOICE project for making possible the study of the BIOICE octocoral material at the Sandgerdi Marine Centre in Iceland. One of us (PJL-G) acknowledges financial support for a visit to the Sandgerdi Marine Centre (Iceland) under the EC-funded TMR BIOICE Large-Scale Facility Programme.

\section{REFERENCES}

Bayer, F.M. - 1959. Octocorals from Surinam and the adjacent coasts of South America. Stud. Fauna Suriname and other Guyanas, 6:1-43.

Bayer, F.M. - 1961. The shallow-water Octocorallia of the West Indian region. A manual for marine biologists. Stud. Fauna Curacao and other Caribbean Islands ,12:1-373.

Broch, H. - 1910. Anthozoa (Nachtrag): Pennatuliden. In: Schultze, L. (ed.), Zoologische und anthropologische Ergebn.. Forsch. westl. zen.Sudafr., 1903-1905, pp. 4:231-235. Verlag von Gustav Fischer, Jena.

Broch, H. - 1914. Pennatulacea. In: W. Michaelson (ed.), Beitrage zur Kenntnis der Meerefauna Westafricas, pp. 51-56. L. Friederichsen and Co., Hamburg.

Broch, H. - 1958. Octocorals, Part I. Discovery Rep., 29: 245-280.

Buchanan, J.B. - 1955. The Pennatulacea of the Gold Coast. Rev. zool. bot. afric., 51(1-2): 380.390 .

Dollfus, R.P.H. - 1938. Sur un octocoralliaire du genre Cavernularia, commun sur les fonds cotiers de l'Atlantique Marocain. Trav. Stat. Zool.Wimereux, 13: 243-265.

Gili, J.M., Vervoort, W. and F. Pagès. - 1989. Hydroids from the West African coast: Guinea Bissau, Namibia and South Africa. Sci. Mar., 53: 67-112.

Grasshoff, M - 1982a. Die Gorgonaria, Pennatularia und Antipatharia des Tiefwassers der Biskaya (Cnidaria, Anthozoa). Ergebnisse der französischen Expedition Biogas, Polygas, Geomanche, Incal, Noratlante und Fahrten der 'Thalassa'. I. Allgemeiner Teil. Bull. Mus. Natl. Hist. Nat. Sec. A: Zool. Biol. Ecol. Ani, 3: 731-766.

Grasshoff, M. - 1982b. Die Gorgonaria, Pennatularia und Antipatharia des Tiefwassers der Biskaya (Cnidaria, Anthozoa). Ergebnisse der französischen Expedition Biogas, Polygas, Geomanche, Incal, Noratlante und Fahrten der 'Thalassa'. II.
Taxonomicher Teil. Bull. Mus. Natl. Hist. Nat., Sec. A: Zool. Biol. Ecol. Ani., 3: 941-978.

Grasshoff, M. - 1989. Die Meerenge von Gibraltar als FaunenBarriere: die Gorgonaria, Pennatularia und Antipatharia der BALGIM-Expedition. Senckenb. marit. 20(5/6): 201-223.

Keller, N.B., Pasternak, F.A. and D.V. Naumov. - 1975. Bottom deep-sea Coelenterata from the Gulf and Caribbean. Scientific studies Caribbean Sea, Gulf of Mexico and adjacent waters. Trans. P.P. Shirsov Inst. Oceanol., 100: 147-159.

Kükenthal, W. - 1915. Pennatularia. Das Tierreich , 4 3: 1-132.

López-González, P.J. - 1993. Taxonomía y Zoogeografia de los Antozoos del Estrecho de Gibraltar y áreas próximas. Ph. D. Thesis. University of Seville. 569 pp.

López-González, P.J., Gili, J.M. and G.C. Williams. - 2000. On some veretillid pennatulaceans from the eastern Atlantic and western Pacific Oceans (Anthozoa: Octocorallia), with a review of the genus Cavernularia, and descriptions of new taxa. $J$. Zool. Lond., 250: 201-216.

Macpherson, E. - 1984. Crustáceos Decápodos del Banco Valdivia (Atlántico suroriental). Res. Exped. cient. (Suppl. Inv. Pesq.), 12: $39-105$.

Manuel, R.L. - 1981. British Anthozoa. Synopses of the British fauna (New Series). Linnean Society of London.

Molander, A.R. - 1929. South and West African Octactiniae in the Gothenburg Natural History Museum. Kungl. Vetenskaps och Vitter-hets Samhalles Handl. (5) Ser. B, Band 1, No.7: 1-16.

Olivar, M.P. and J.M. Fortuño. - 1985. Guide to Ichthyoplankton of the southeast Atlantic (Benguela Current Region). Sci. Mar., 55: $1-383$

Pagès, F., Gili, J.M. and J. Bouillon. - 1992. Planktonic Cnidarians of the Benguela Current. Sci. Mar., 56 (Supl. 1): 1-144.

Patriti, G. -1970. Classe des Anthozoaires. In: Catalogue des Cnidaires et Ctenaires des cotes atlantiques marocaines. Trav. Inst. Sci. Cherifien Fac. Sci. (Serie Zool.), 35: 99-143.

Pax, F. and I. Müller. - 1954. Veretillum cynomorium an der küste von Angola. Ann. Mus. Congo belge, Zool. 1: 231-237.

Shannon, L.V. - 1985. The Benguela ecosystem. Part I. Evolution of the Benguela, physical, features and processes. Oceanogr. Mar. Biol. Ann. Rev., 23: 105-182.

Studer, T. - 1878. Über die mit dem Schleppnetz angestellten Untersuchungen an der Westküste von Afrika während der Reise S.M.S. Gazelle. Sitzungsberichte der Gesellschaft naturforschender Freude zu Berlin, 1878: 135-139.

Tixier-Durivault, A. - 1954. Les Octocoralliaires d'Afrique du Sud (II - Gorgonacea; III - Pennatulacea). Bull. Mus. Natl. Hist. Nat. $\left(2^{a}\right.$ S., XXVI) 5: 624-631.

Tixier-Durivault, A. - 1960. Les octocoralliaires de L'Ile Inhaca. Bull. Mus. Natl. Hist. Nat. (2 ${ }^{a}$ S., XXXII), 4: 359-367.

Tixier-Durivault, A. - 1961. Les Octocoralliaires du Golfe du Guinée et des Iles du Cap-Vert. Campagne de la "Calypso": Golfe de Guinée. Ann. Inst. Océanogr. Monaco, 39: 237-262.

Tixier-Durivault, A. - 1963. Alcyonacea et Pennatulacea de l'Afrique occidentale. Atlantide Report. Scientific Results of the Danish Expedition to the Coasts of Tropical West Africa, 19451946, 7: 63-76.

Tixier-Durivault, A. and M-J. d'Hondt. - 1973. Nouvelles recoltes d'Octocoralliaires a Madagascar. Tethys, 5: 251-266.

Uriz, M.J. - 1988. Deep-water sponges from the continental shelf and slope off Namibia (Soutwest Africa): Classes Hexactinellida and Demospongia. Monogr. Zool. Mar. Barcelona, 3: 9-157.

Williams, G.C. - 1987. Systematic and zoogeography of southern African octocoral cnidarians. Ph. D. dissertation, University of Cape Town, South Africa. $469 \mathrm{pp}$.

Williams, G.C. - 1989. The pennatulacean genus Cavernularia Valenciennes (Octocorallia: Veretillidae). Zool. J. Linn. Soc., 95(4): 285-310.

Williams, G.C. - 1990. The Pennatulacea of southern Africa (Coelenterata, Anthozoa). Ann. S. Afr. Mus., 99: 31-119.

Williams, G.C. - 1992. Biotic diversity, biogeography, and phylogeny of pennatulacean octocorals associated with coral reefs in the Indo-Pacific. Proc. Seventh Inter.Coral Reef Symp., Guam , 2: 729-735.

Williams, G.C. - 1995. Living genera of sea pens (Coelenterata: Octocorallia: Pennatulacea): illustrated key and synopses. Zool. J. Linn. Soc. 113: 93-140.

Williams, G.C. - 1999. Index Pennatulacea. Annotated bibliography and indexes of the sea pens (Coelenterata: Octocorallia) of the world 1469-1999. Proc. Calif. Acad. Sci., 51(2): 19-103. 
Zamponi, M.O. and C.D. Pérez. - 1996. La presencia de la familia Virgulariidae Verrill, 1868 (Octocorallia, Pennatulacea) en la plataforma continental argentina. Ann. Mus. Civ. Stor. Nat. "G. Doria”, 91: 65-79.

Zibrowius, H. and J.M. Gili. - 1990. Deep-water Scleractinia
(Cnidaria: Anthozoa) from Namibia, South Africa, and Walvis Ridge, southern Atlantic. Sci. Mar., 54: 19-46.

Scient. ed.: R. Hughes 